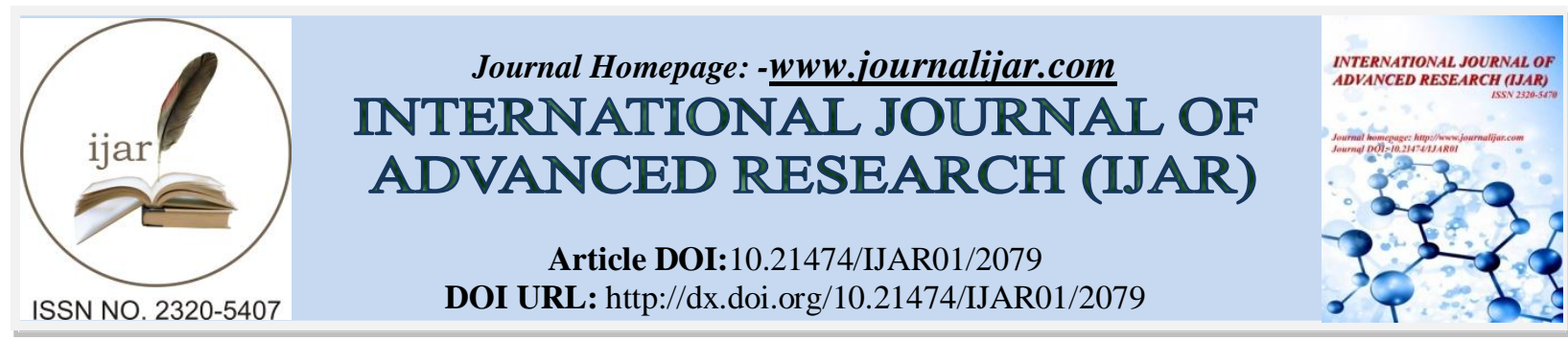

RESEARCH ARTICLE

\title{
RISK ASSESSMENT OF RADIONUCLIDES AND HEAVY METALS IN GROUND WATER IN SELECTED WATER WELLS IN NORTHWESTERN OF EGYPT.
}

\author{
M. M. Shaban ${ }^{1}$ and I. H. Shady ${ }^{2}$ \\ 1. Chemist, EL-Beheira Water and Drainage Company, Egypt. \\ 2. Department of Environmental Studies, Institute of Graduate Studies and Research, Alexandria University, Egypt.
}

\section{Manuscript Info}

Manuscript History

Received: 24 September 2016

Final Accepted: 26 October 2016

Published: November 2016

Key words:-

Groundwater; ${ }^{226}$ Ra;radiotoxicity;trace meals; chemotoxicity

\section{Abstract}

${ }^{226} \mathrm{Ra},{ }^{228} \mathrm{Ra}$ and ${ }^{40} \mathrm{~K}$ radioactivity were analyzed and their radiotoxicity were assessed in drinking water samples collected from groundwater wells in El-Beheira governorate, Northwestern of Egypt. The average activity concentration of ${ }^{226} \mathrm{Ra},{ }^{228} \mathrm{Ra}$ and ${ }^{40} \mathrm{Kvalues}$ in the study areas $4.59,0.583$ and $7.187 \mathrm{~Bq} / 1$, respectively. Three wells only were complying with WHO (2011) guidance level for ${ }^{226} \mathrm{Ra}$ radionuclides for members of the public $(1 \mathrm{~Bq} / \mathrm{l})$. The total annual effective doses radiation during water consumption for $\left({ }^{226} \mathrm{Ra},{ }^{228} \mathrm{Ra}\right.$ and ${ }^{40} \mathrm{~K}$ ) in the study areas for adults estimated to range from 0.208 to $3.716 \mathrm{mSvy}^{-1}$, which are much higher than the reference level of the committed effective dose recommended by the WHO ( $0.1 \mathrm{mSvy}^{-}$

$\left.{ }^{1}\right)$.Properactions must be taken to treatment the groundwater from radionuclides in this areas to protect the population in the study areas. Additionally, $\mathrm{Fe}, \mathrm{Mn}, \mathrm{Zn}$ and $\mathrm{Cu}$ trace meals were measured in the same samples and their chemotoxicity were assessment. Theaverage concentrationare $0.35, \quad 0.45, \quad 0.08$ and $0.05 \mathrm{mg} / 1$,respectively. The majority of the studied wells fortrace meals complying with Egyptian permissible limit .Risk assessment due to intake of heavy metals around study areas where hazard quotient and hazard index is less than 1 meaning that no significant risk or systemic toxicity on the exposed population.

Copy Right, IJAR, 2016,. All rights reserved.

\section{Introduction:-}

In Egypt, groundwater is considered the third water source for irrigation and other human uses after the River Nile, and irrigation canals and drains. In many parts of the Nile Delta area ground water is widely used for drinking and other domestic purposes (Fahimet al.1995). Fresh groundwater resources in Egypt contribute to some 20\% of the total potential of water resources in Egypt (Allamet al.2002). Groundwater is an important source of domestic, industrial and agricultural water Supply in the world. It is estimated that approximately one-third of the world's population use groundwater for drinking (Nicksonet al.2005) Therefore, groundwater is a valuable resource and it must be protected from any pollution.

Corresponding Author: -M. M. Shaban.

Address: -Chemist, EL-Beheira Water and Drainage Company, Egypt. 
It is critical that the groundwater contamination must be prevented and the contaminated groundwater at numerous sites worldwide be remediated in order to protect public health and the environment (Rowland, 1993). Measurements of natural radioactivity in drinking water have been performed in many parts of the world, mostly for assessment of the doses and risk resulting from consuming water (EL.Gamal et al. 2012).Human exposure to ionizing radiation is one of the scientific subjects that attracts most public attention (Badawy et al. 2015). Natural radionuclides, including potassium-40, and those of the thorium and uranium decay series, in particular radium-226, radium-228, uranium-234, uranium-238 and lead-210, can be found in water as a result of either natural processes(e.g. absorption from the soil) or technological processes involving naturally occurring radioactive materials (e.g. the mining and processing of mineral sands or phosphate fertilizer production)(WHO 2011). The most radiotoxic and most important radionuclides are radium, which is a known carcinogen and exists in several isotopic forms(Ahmed, 2004).Considering the high radiotoxicity of ${ }^{226} \mathrm{Ra}$ and ${ }^{228} \mathrm{Ra}$, their presence in water and the associated health risks require particular attention. It is known that even small amounts of a radioactive substance may produce a damaging biological effect and that ingested and inhaled radiation can be a serious health risk (Rowland, 1993).

When radium is taken into the body, its metabolic behavior is similar to that of calcium and an appreciable fraction is deposited in bone, the remaining fraction being distributed almost uniformly in soft tissues (Wrenn et al. 1985). When people are exposed to very high levels of radium for a long period, cancer of the bone and nasal cavity may result. Radium is highly radiotoxic and it builds up in the growing bones of babies and children where it can cause bone cancers(Ajayi and Adesida 2009)An important aspect of radium protection is the prevention of its entry into the human body, the critical pathway being ingestion through the food chain or drinking water (Ahmed, 2004).

Heavy metals are stable and are extremely persistent environmental contaminants since they cannot be degraded nor destroyed. They produce adverse effects on health of human and other living beings in terrestrial and aquatic environment and affect the food chain (Sevgi et al. 2009).

\section{Materials and Methods:-}

\section{Study areas:-}

The study areas consisted of three areas at El-Beheira governorate,northwestern of Egypt figur1. They are, Wadi EL- Natrun, Kom Hamada and El-Dilingat regions, domestic, industrial and agricultural water uses depend mainly on groundwater resources in these regions. El-Beheira governorate lies in the west of Delta region. It is bordered in the north by the Mediterranean Sea.Wadi EL- Natrun wells is located in the extreme arid zone with average annual rainfall of $55 \mathrm{~mm} /$ year and potential evapotranspiration is about $8.5 \mathrm{~mm} /$ day (EL-Awady et al. 1997), where Kom Hamada and El-Dilingat wells located in agricultural land.

\section{Collection of the samples:-}

The water samples were collected from 12 productive wells distributed in the three districts, Wadi El-Natrun, Kom Hamada and El-Dilingat regions figure 2 the samples collected during October, November and December month of 2013.Radionuclides measurementssample bottles were washed out with the filtered water to be sampled,Water was acidified immediately with nitric acid, evaporation technique was used to concentrate the samples from 5L to1 L for radionuclides measurements. Each water sample was collected in 1-liter new plastic bottle polyethylene for measurement heavy metals.

\section{Radioactivity measurements:-}

The radionuclides in groundwater was measured by gamma spectrometry system the method used were according to (IAEA) these radionuclides includes:-

a. Radium-226,b. Radium-228,c. Single Potassium- 40 


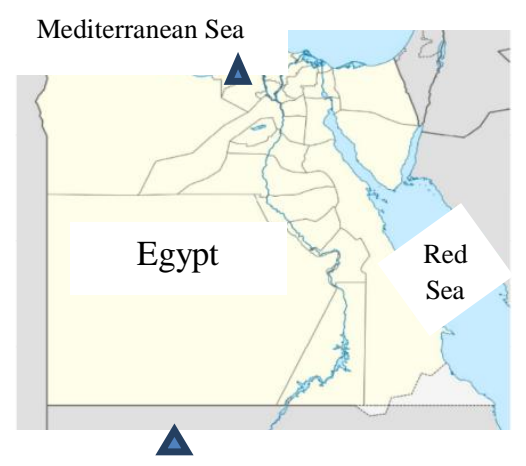

Fig 1:-Study areas

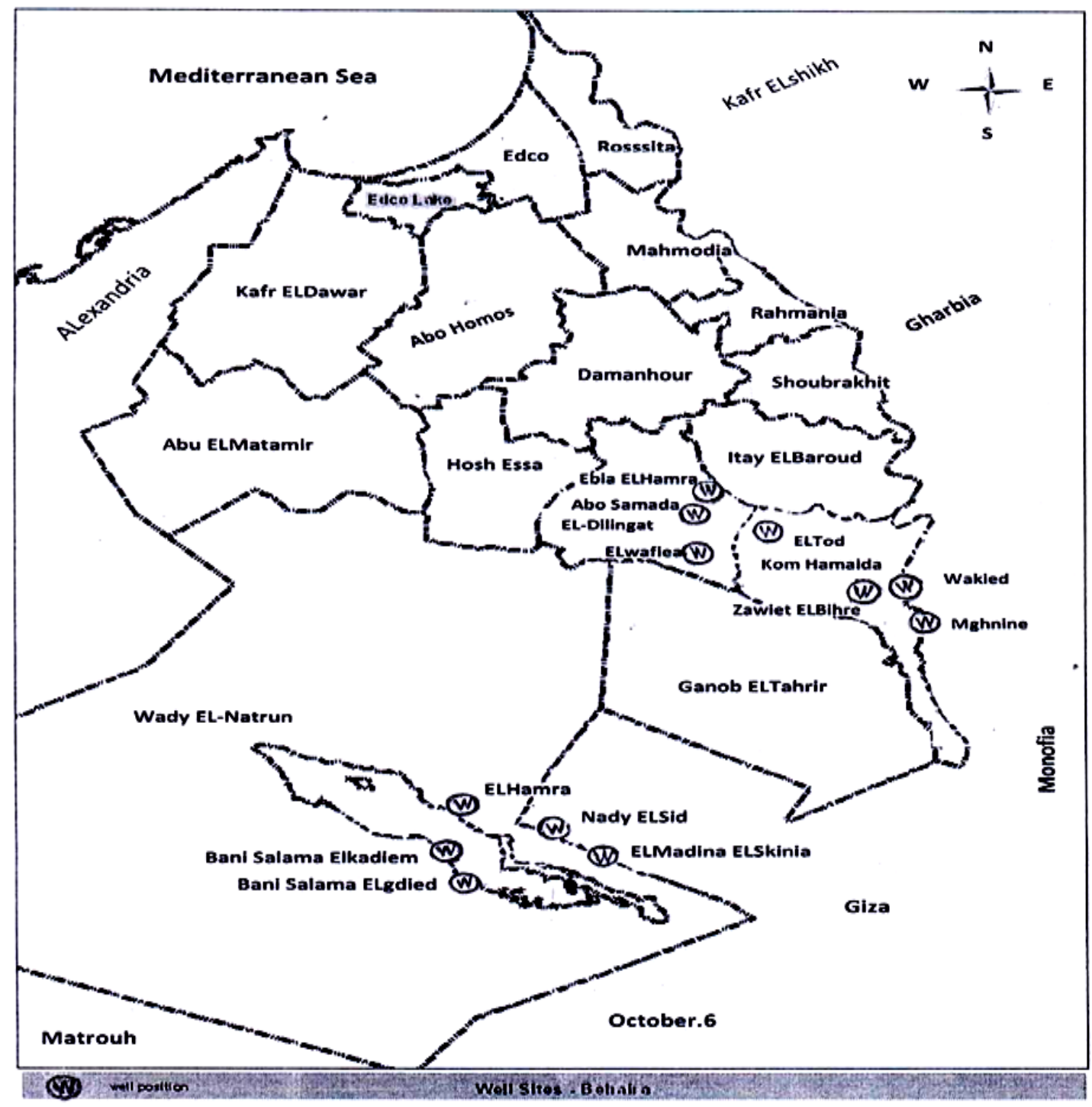

Fig 2:-El- Beheira governorate and locations of the selected wells in study areas

The annual effective doses due to water consumption $\left(\mathrm{mSvy}^{-1}\right)$ :-

The annual effective dose (AED) was calculated with the intake of individual radionuclide and ingestion dose coefficients $\left(\mathrm{mSvBq}^{-1}\right)$ reported by the International Commission on Radiological Protection (ICRP). 
The calculating the annual effective dose (AED) per person is given by Eq. (1).

$\mathbf{A E D}=\boldsymbol{\Sigma} \mathbf{I}_{\mathrm{i}} \cdot \mathbf{3 6 5} \cdot \mathbf{D}_{\mathrm{i}}$

Where Ii is the daily intakes of radionuclide I $\left(\mathrm{Bqd}^{-1}\right)$, and the ingestion dose coefficient $\mathrm{Di}$ for ${ }^{226} \mathrm{Ra},{ }^{228} \mathrm{Ra}$ and ${ }^{40} \mathrm{~K}$ where Dose coefficient for ingestion for radionuclides by adult members of the public. (mSv/Bq) respectively $\left(2.8 \times 10^{-4}, 6.9 \times 10^{-4}\right.$ and $\left.6.2 \times 10^{-6}\right)$ Data supplies(IAEA, 1996;WHO, 2011)

Radiation risk characterizations:-

The risk incurred by the consumer is estimated by assuming linear dose-effect relationship with no threshold as per international commission on radiological protection (ICRP, 2008, WHO, 2011)practice. For low doses ICRP fatal cancer risk factor is $0.055 \mathrm{~Sv}^{-1}$. The cancer risk was estimated using the following the Eq. (2).

Risk $=$ Dose $(\mathrm{Sv}) \times$ Risk factor $\left(\mathbf{S v}^{-1}\right)$

The estimated cumulative annual dose to using life-time (70yr.) exposure, the Eq. (3) can be written as the following the Eq. (3) (Tawalbeh et al. 2012).

Risk $=$ Dose $(\mathrm{Sv}) \times 0.055\left(\mathrm{~Sv}^{-1}\right) \times \mathbf{7 0}(\mathrm{yr}$.

\section{Heavy metals measurements:-}

Heavy metals (iron, manganese, zinc and copper) measured by using atomic absorption technique (AAs) (thermo elemental dueel beam $-\mathrm{UK})$.

Risk assessment for inorganic chemicals:-

The risk assessment for inorganic chemical can be carried out by calculating the exposure dose through ingestion of water by using the following the Eq. (4) (OEHHA, 2003).

Where:

$$
\text { Dose }-w=\frac{\text { CwxWIRxABingxEFxEDx10-6 }}{\text { AT }}(4)
$$

Dose-w; Exposure dose through ingestion of water $(\mathrm{mg} / \mathrm{kg} / \mathrm{d})$

$\mathrm{Cw}$; Water concentration $(\mu \mathrm{g} / \mathrm{l})$

WIR; Water ingestion rate $(\mathrm{ml} / \mathrm{kg} \mathrm{BW} /$ day $)$

ABing; Gastrointestinal absorption factor

EF; Exposure frequency (days/year)

ED; Exposure duration (years)

$10^{-6}$; Conversion factor $(\mu \mathrm{g} / \mathrm{mg})(1 / \mathrm{ml})$

AT; 25,550 days

Risk characterization for chronic health effects from exposure via the oral route is also conducted by using the hazard index approach. The hazard quotient (HQ) is obtained by Eq. (5).(OEHHA, 2003).

$$
\text { Hazard Quotient Oral }=\frac{\text { ExposurePathwayDose }(\mathrm{mg} / \mathrm{kg}-\mathrm{day})}{\text { Chronic }(\text { oral }) \text { ReferenceExposureLevel }(\mathrm{mg} / \mathrm{kg}-\text { day })}
$$

The hazard quotient (HQ) has been defined so that if it is less than 1.0, there should be no significant risk or systemic toxicity. The HQ $<1$ means the exposed population is assumed to be safe. Ratios above 1.0 represent a potential risk. When exposure involves more than one chemical, the sum of each the individual hazard quotient for each chemical used as a measure of the potential for harmful. This sum of each individual hazard is called the hazard index (HI) Eq. (6) (Gerba ,2006 ).

Where $\mathrm{n}$ is number of chemicals.

$$
\mathrm{HI}=\sum_{i=1}^{n} H Q
$$

\section{Results and Discussion:-}

\section{Result of the average level of radionuclides in the investigated groundwater (Bq/l):-}

${ }^{226}$ Ra:-

The data in Table1 show that the activity concentration of ${ }^{226} \mathrm{Ra}$ values in the study areas ranged from $<0.05$ to 16.55 $\mathrm{Bq} / \mathrm{l}$ and average value $4.59 \mathrm{~Bq} / \mathrm{l}$, the minimum value was recorded in Mghnine and BaniSalamaElgdied well in 
Wadi El-Natrun area where the maximum value was recorded in ZawietElbihre well in Kom Hamada area this raising due to geological of the area where the predominance of bicarbonate ion. The chemical properties of radium are similar to other alkaline earth elements, particularly barium and calcium. And radium is most mobile in aquifers with high concentrations of dissolved solids (Benes et al., 1984;1985).

Three wells only were complying with (WHO, 2011) guidance level for ${ }^{226}$ Ra radionuclides for members of the public $(1 \mathrm{~Bq} / \mathrm{l})$ are BaniSalamaElgdied well, ELHamra well and Mghnine well. Radium is highly radiotoxic and it builds up in the growing bones of babies and children where it can cause bone cancers (Ajayi and Adesida ,2009). Therefore the use of these water for babies should be discouraged in this areas. People of suffer substantial internal exposure from these drinking waters. These results were in agreement with (El-Gamal et al., 2013) studied the activity concentrations of ${ }^{226} \mathrm{Ra}$ on water samples collected around Assiut Thermal Power Plant (ATPP), Upper Egypt. Two samples were collected from the pond and three samples from groundwater wells, which are quite close to the plant. The concentrations of ${ }^{226} \mathrm{Ra}$, ranged from 1.83 to $18.53 \mathrm{~Bq}^{-1}$.

${ }^{228}$ Ra:-

The data presented inTable 1 show that the activity concentration of ${ }^{228} \mathrm{Ra}$ values in the study areas ranged from 0.173 to $2.398 \mathrm{~Bq} / \mathrm{l}$ and average value $0.583 \mathrm{~Bq} / \mathrm{l}$, the minimum value was recorded in Abo Smada well in ElDilingat area where the maximum value was recorded in Elwfiea well in El-Dilingat area this raising due to geological of the area.It was noticed that in study areas the activity concentration of ${ }^{226} \mathrm{Ra}$ values is greater than the activity concentration of ${ }^{228} \mathrm{Ra}$.All studied wells were not complying with (WHO,2011) guidance level for ${ }^{228} \mathrm{Ra}$ radionuclides for members of the public $(0.1 \mathrm{~Bq} / \mathrm{l})$.

These results were in agreement with (Ajayi and Adesida, 2009) studied the activity concentrations of ${ }^{228} \mathrm{Ra} . \mathrm{On}^{2}$ groundwater two samples per brand of fifteen different sachet water samples ( from ground water) making a total of 30 samples, were bought from their different producers in Akure, southwestern Nigeria. The activity concentrations of ${ }^{228} \mathrm{Ra}$, value varied from $0.04 \pm 0.01$ to $7.04 \pm 1.16 \mathrm{~Bq} 1-11$ with mean $2.03 \pm 1.95 \mathrm{~Bq}^{-1}$.

\section{${ }^{40}$ K single:-}

The data presented in Table 1 show that the activity concentration of ${ }^{40} \mathrm{~K}$ values in the study areas ranged from 1.694 to $10.07 \mathrm{~Bq} / \mathrm{l}$ and average value $7.187 \mathrm{~Bq} / \mathrm{l}$, the minimum value was recorded in NadyElsid well in Wadi El-Natrun area where this well site on elevated area on the sea surface of 63 meters. The maximum value was recorded in BaniSalamaElgdied well in Wadi El-Natrun area this raising due to geological of the area.

Table.1:-The average levels of radionuclides in the investigated groundwater $(\mathrm{Bq} / \mathrm{l})$.

\begin{tabular}{|l|c|c|c|}
\hline Well name & ${ }^{\mathbf{2 2 6}} \mathbf{R a}$ & ${ }^{\mathbf{2 2}} \mathbf{R a}$ & ${ }^{\mathbf{4 0}} \mathbf{k}$ \\
\hline BaniSalamaElkadiem & 4.47 & 0.829 & 6.438 \\
\hline BaniSalamaElgdied & $<0.05$ & 0.324 & 10.07 \\
\hline El MadinaElsakinia & 5.22 & 0.372 & 7.629 \\
\hline NadyElsid & 4.57 & 0.362 & 1.694 \\
\hline EL Hamra & 0.91 & 0.283 & 7.899 \\
\hline Mghnine & 0.66 & 0.216 & 6.451 \\
\hline Wakied & 2.53 & 0.398 & 8.19 \\
\hline ZawietElbihre Min. & 16.55 & 0.603 & 6.344 \\
\hline El Tod Max. & 3.35 & 0.538 & 8.304 \\
\hline Elwfiea & 2.77 & 2.398 & 8.307 \\
\hline Abo Smada & 5.55 & 0.173 & 7.061 \\
\hline EbiaElHamra & 3.93 & 0.507 & 7.860 \\
\hline \multicolumn{1}{|c|}{} & 16.55 & 0.173 & 1.694 \\
\hline & 4.59 & 2.398 & 10.07 \\
\hline
\end{tabular}

DL: 0.05 for ${ }^{226} \mathrm{Ra}$

Increasing in the radionuclide concentration levels has various health effects on the populace. These could be genetic or somatic; the genetic effects could be transferred to offspring while somatic effects could ultimately lead to death depending on the level of exposure. These results were in agreement with (El-Gamal et al., 2012) studied the activity concentrations of ${ }^{40} \mathrm{~K}$ on fifteen water samples collected from Assiut, Upper Egypt. 13 water samples 
collected from open wells, 2 drinking water samples were taken from the tap water system. Water activity ranged from 3.25 to $8.72 \mathrm{Bql}-1$ for ${ }^{40} \mathrm{~K}$ with mean values of $5.29 \mathrm{Bql}-1$.

Result of total annual effective radiation doses during water consumption $(\mathrm{mSv} / \mathrm{y})$ for $\left({ }^{226} \mathrm{Ra}\right.$, ${ }^{228} \mathrm{Ra}$ and $\left.{ }^{40} \mathrm{~K}\right)$ :Figure 3 shows that the total annual effective radiation doses during water consumption for $\left({ }^{226} \mathrm{Ra},{ }^{228} \mathrm{Ra}\right.$ and $\left.{ }^{40} \mathrm{~K}\right)$ in the study areas (Wadi El-Natrun, Kom Hamada and El-Dilingat) for adults( where annual average water intake 730 liters) is estimated be ranged from 0.208 to $3.716 \mathrm{mSvy}^{-1}$ with an average of 1.275 ; the minimum value was recorded in BaniSalamaElgdied well in Wadi El-Natrun area and the maximum value was recorded in ZawietElbihre well in Kom Hamada area.

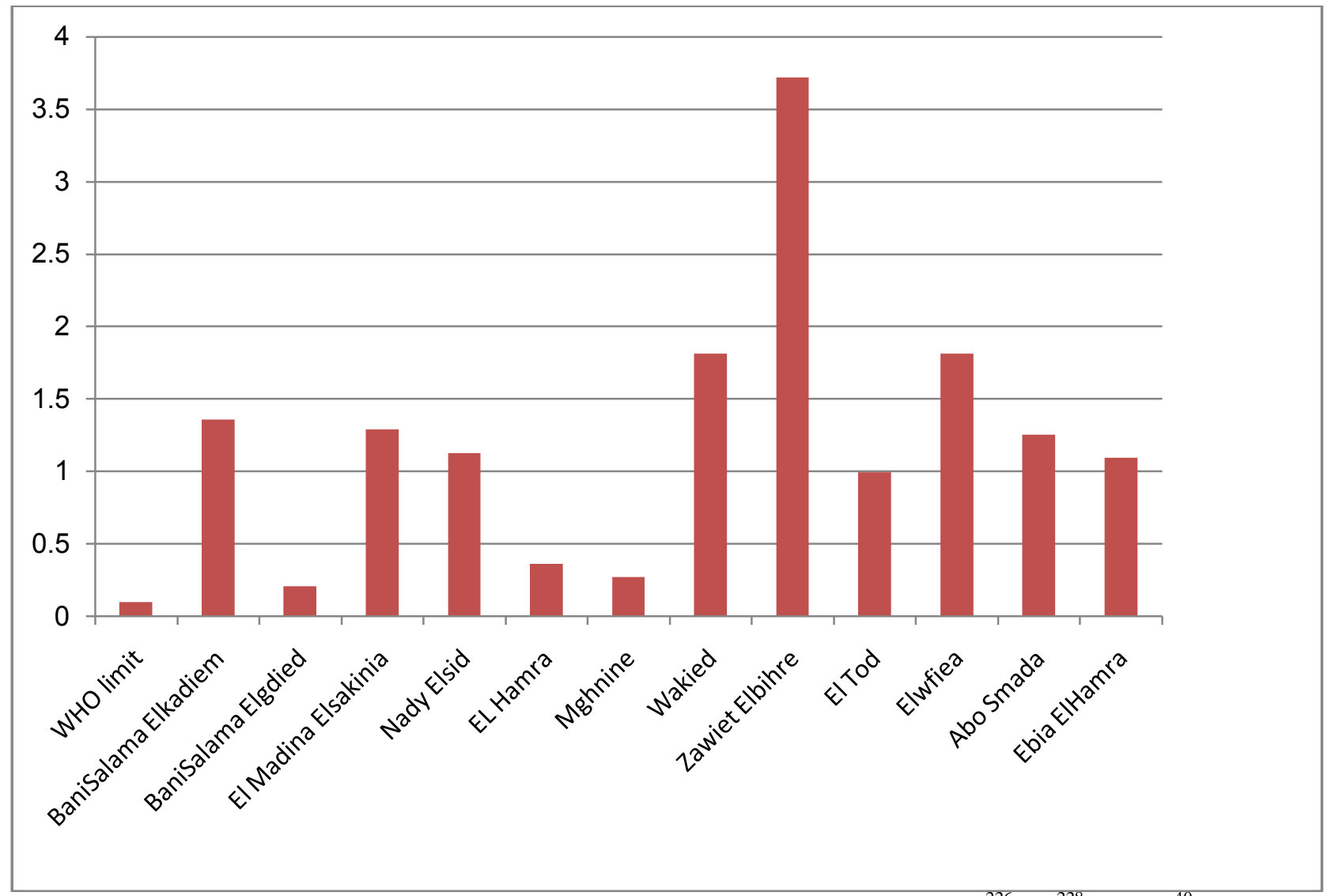

Fig3:- The total annual effective radiation doses during water consumption (mSv/y) for $\left({ }^{226} \mathrm{Ra}^{228} \mathrm{Ra}^{\text {and }}{ }^{40} \mathrm{~K}\right)$

Was noticed that the total annual effective radiation doses during water consumption for all wells in the study area are much higher than the reference level of the committed effective dose recommended by the WHO $\left(0.1 \mathrm{mSvy}^{-1}\right)$, the use of these wells for drinking water for babies should be discouraged in the study areas.

These results were in agreement with (Ajayi and Adesida ,2009) who studied the activity concentrations of ${ }^{40} \mathrm{~K}$,

${ }^{226} \mathrm{Ra}$, and ${ }^{228} \mathrm{Ra}$ on groundwater two samples per brand of fifteen different sachet water samples, (from groundwater) making a total of 30 samples, were bought from their different producers in Akure, southwestern Nigeria. The total annual effective doses varied from 0.68 to $5.04 \mathrm{mSv} \mathrm{y}^{-1}$ for adults (age from 17 year and above) due to the intake of ${ }^{226} \mathrm{Ra}$, and ${ }^{228} \mathrm{Ra}$, where annual average water intake 730 liters. Doses obtained from one year of consumption of drinking water are much higher than the recommended reference level.

Result ofthe annual cancer risk due to water consumption in the study areas:-

The data in Table 2show that the annual cancer risk dose due to water consumption in the study areas 
Table2:- The annual cancer risk due to water consumption in the study areas.

\begin{tabular}{|c|c|c|c|}
\hline Well no. & Areas & Well name & Annual cancer risk \\
\hline WHO limit & & & $5.5 \times 10^{-6}$ \\
\hline 1 & Wadi El-Natrun & BaniSalamaElkadiem & $74 \times 10^{-6}$ \\
\hline 2 & Wadi El-Natrun & BaniSalamaElgdied & $11 \times 10^{-6}$ \\
\hline 3 & Wadi El-Natrun & ElMadinaElsakinia & $70 \times 10^{-6}$ \\
\hline 4 & Wadi El-Natrun & NadyElsid & $61 \times 10^{-6}$ \\
\hline 5 & Wadi El-Natrun & ELHamra & $20 \times 10^{-6}$ \\
\hline 6 & Kom Hamada & Mghnine & $15 \times 10^{-6}$ \\
\hline 7 & Kom Hamada & Wakied & $99 \times 10^{-6}$ \\
\hline 8 & Kom Hamada & ZawietElbihre & $204 \times 10^{-6}$ \\
\hline 9 & Kom Hamada & El Tod & $54 \times 10^{-6}$ \\
\hline 10 & El-Dilingat & Elwfiea & $99 \times 10^{-6}$ \\
\hline 11 & El-Dilingat & Abo Smada & $69 \times 10^{-6}$ \\
\hline 12 & El-Dilingat & EbiaElHamra & $60 \times 10^{-6}$ \\
\hline Min. & & & $11 \times 10^{-6}$ \\
\hline Max. & & & $204 \times 10^{-6}$ \\
\hline Average & & & $69.6 \times 10^{-6}$ \\
\hline
\end{tabular}

(Wadi El-Natrun, KomHamada and El-Dilingat) for all wells is estimated to range from $11 \times 10^{-6}$ to $204 \times 10^{-6}$ with an average of $69.6 \times 10^{-6}$ the minimum value was recorded in BaniSalamaElgdied well in Wadi El-Natrun area and the maximum value was recorded in ZawietElbihre well in Kom Hamada area. It is noticed that the annual cancer risk dose due to water consumption in the study areas were much higher than the reference level recommended by the WHO $\left(5.5 \times 10^{-6}\right)$ consequently, it can be recommended that the investigated water is not acceptable radiological for human health long- life consumption and a reduction in consumption or radionuclide concentration is essential.

Result of the dose risk incurred by population along -life-time (70 year) due to water consumption in the study areas:-

The data presented in Table 3shows that the dose risk incurred by population along -life-time (70 yr.) due to water consumption in the study areas (Wadi El-Natrun, Kom Hamada and El-Dilingat), for all wells is estimated to range from $770 \times 10^{-6}$ to $14000 \times 10^{-6}$ with an average of $4853 \times 10^{-6}$, the minimum Value was recorded in BaniSalamaElgdied well in Wadi El-Natrun area and the maximum value was recorded in ZawietElbihre well in Kom Hamada area. Proper actions must be taken to treatment the groundwater from radionuclides in these areas to protect the population.

Table 3:-The dose risk incurred by population along -life-time (70 year) in the study areas.

\begin{tabular}{|c|l|l|c|}
\hline Well no. & \multicolumn{1}{|c|}{ Sites } & \multicolumn{1}{|c|}{ Well name } & Life-time risk \\
\hline 1 & Wadi El-Natrun & BaniSalamaElkadiem & $5180 \times 10^{-6}$ \\
\hline 2 & Wadi El-Natrun & BaniSalamaElgdied & $770 \times 10^{-6}$ \\
\hline 3 & Wadi El-Natrun & ElMadinaElsakinia & $4900 \times 10^{-6}$ \\
\hline 4 & Wadi El-Natrun & NadyElsid & $4270 \times 10^{-6}$ \\
\hline 5 & Wadi El-Natrun & ELHamra & $1400 \times 10^{-6}$ \\
\hline 6 & KomHamada & Mghnine & $1050 \times 10^{-6}$ \\
\hline 7 & KomHamada & Wakied & $6930 \times 10^{-6}$ \\
\hline 8 & KomHamada & ZawietElbihre & $14000 \times 10^{-6}$ \\
\hline 9 & KomHamada & El Tod & $3780 \times 10^{-6}$ \\
\hline 10 & El-Dilingat & Elwfiea & $6930 \times 10^{-6}$ \\
\hline 11 & El-Dilingat & Abo Smada & $4830 \times 10^{-6}$ \\
\hline 12 & El-Dilingat & EbiaElHamra & $4200 \times 10^{-6}$ \\
\cline { 1 - 3 } Min. & & & $770 \times 10^{-6}$ \\
\cline { 1 - 3 } Max. & & & $14000 \times 10^{-6}$ \\
\cline { 1 - 3 } Average & & & $4853 \times 10^{-6}$ \\
\hline
\end{tabular}




\section{Results of trace meals in the investigated groundwater in study areas:- Iron, Fe:-}

In Table 4 show that the iron ion values ranged from $<0.05$ to $0.77 \mathrm{mg} / \mathrm{l}$ and average value $0.35 \mathrm{mg} / \mathrm{l}$, the minimum value was recorded in El MadinaElskinia, NadyElsid, Mghnine and El Tod well where the maximum value was recorded in BaniSalamaElkadiem well inWadi EL- Natrun area this raising due to geological and hydrogeological of the area and also there are a lot of the salt lakes, marches and lagoonal surrounding the BaniSalamaElkadiem well. The majority of the studied wells were complying with Egyptian permissible Limit (Egyptian Ministry of Health,2007) of iron $0.3 \mathrm{mg} / \mathrm{l}$. These results were in agreement with(El-Naggar ,2010) studiedthe iron ontwenty-five groundwater samples collected from Siwa and Aghurmi in Siwa oasis, Egypt,the min. concentration 0.934, max. Concentration 1.23 and mean $1.14 \mathrm{mg} / \mathrm{l}$.

\section{Manganese, Mn:-}

The data presented in Table 4 show that the manganese ion values ranged from $<0.05$ to $1.4 \mathrm{mg} / \mathrm{l}$ and average value $0.45 \mathrm{mg} / \mathrm{l}$, the majority of wells (92\%) were complying with Egyptian permissible limit (Egyptian Ministry of Health, 2007) of manganese $0.4 \mathrm{mg} / \mathrm{l}$ except EbiaElHamra well in El-Dilingat area (1.4 mg/l).

These results were in agreement with (Stamatis et al., 2001) studied manganese on thirty-three groundwater samples in the Lavrio area Greece the concentration of manganese ranged from 0.001 to $4.21 \mathrm{mg} / \mathrm{l}$ (mean of $0.23 \mathrm{mg} / \mathrm{l}$ ) in unconfined aquifer and the concentration of manganese ranges from 0.002 to $0.15 \mathrm{mg} / \mathrm{l}$ (mean of $0.029 \mathrm{mg} / \mathrm{l}$ ) in Karst aquifer where the high concentrationwas due to the intensive mining activities that were carried outfor centuries

Table. 4:-The concentration of trace meals of the groundwater in the study areas ( $\mathrm{mg} / \mathrm{l})$

\begin{tabular}{|c|c|c|c|c|}
\hline Well name & Iron & Manganese & Zinc & Copper \\
\hline BaniSalamaElkadiem & 0.77 & $<0.05$ & $<0.05$ & $<0.05$ \\
\hline BaniSalamaElgdied & 0.1 & $<0.05$ & $<0.05$ & $<0.05$ \\
\hline El MadinaElskinia & $<0.05$ & $<0.05$ & $<0.05$ & $<0.05$ \\
\hline NadyElsid & $<0.05$ & $<0.05$ & $<0.05$ & $<0.05$ \\
\hline El Hamra & 0.18 & 0.12 & 0.06 & $<0.05$ \\
\hline Mghnine & 0.08 & 0.4 & $<0.05$ & $<0.05$ \\
\hline Wakied & 0.38 & $<0.05$ & 0.1 & 0.05 \\
\hline ZawietElbihre & 0.29 & 0.3 & $<0.05$ & $<0.05$ \\
\hline El Tod & $<0.05$ & $<0.05$ & $<0.05$ & $<0.05$ \\
\hline Elwfiea & 0.37 & 0.08 & $<0.05$ & $<0.05$ \\
\hline Abo Smada & 0.35 & 0.4 & $<0.05$ & $<0.05$ \\
\hline EbiaElHamra & 0.65 & 1.4 & $<0.05$ & $<0.05$ \\
\hline Min. & $<0.05$ & $<0.05$ & $<0.05$ & $<0.05$ \\
\hline Max. & 0.77 & 1.4 & 0.1 & 0.05 \\
\hline Average & 0.35 & 0.45 & 0.08 & 0.05 \\
\hline
\end{tabular}

$* \mathrm{DL}=0.05$

the area of Lavrio is classified, from an environmental view, as a high risk area.Treating ground water to remove iron and manganese from municipal, agricultural and domestic wells is necessary among the different techniques mentioned; aeration followed by rapid sand filtration is most widely used and is the preferred method in the developing countries.

\section{Zinc, Zn and Copper, Cu:-}

The data presented in Table 4 show that the zinc ion values ranged from $<0.05$ to $0.1 \mathrm{mg} / \mathrm{l}$ and average value 0.08 $\mathrm{mg} / \mathrm{l}$, all wells were complying with Egyptian permissible limit (Egyptian Ministry of Health,2007)of zinc 3.0 $\mathrm{mg} / \mathrm{l}$.The copper ion values ranged from $<0.05$ to $0.05 \mathrm{mg} / \mathrm{l}$ and average value $0.05 \mathrm{mg} / \mathrm{l}$ all wells wereComplying with Egyptian permissible limit of copper $2.0 \mathrm{mg} / \mathrm{l}$.

These results were in agreement with (Ahmed et al., 2011)who studied zinc and copper on 52 wells. In El-Sadat city Egypt 14 shallow groundwater $(<100 \mathrm{~m})$ and 38 deep groundwater the concentration of zinc ranges from 0.007 to $0.361 \mathrm{mg} / \mathrm{l}$ (mean of $0.087 \mathrm{mg} / \mathrm{l}$ ) in shallow well water and from 0.00 to $0.506 \mathrm{mg} / 1($ mean of $0.088 \mathrm{mg} / \mathrm{l})$ in deep well water. The concentration of copper ranged from 0.008 to $0.278 \mathrm{mg} / \mathrm{l}$ (mean of $0.045 \mathrm{mg} / \mathrm{l}$ ) in shallow well water and from 0.00 to $0.293 \mathrm{mg} / \mathrm{l}$ (mean of $0.047 \mathrm{mg} / \mathrm{l}$ ) in deep well water. 
Risk assessment due to intake of heavy metals through the ingestion of ground water around study areas:-

The data presented in Table 5 show that (average hazard quotient (HQ)) for risk assessment due to intake of iron $(\mathrm{Fe})$ metal through the ingestion of groundwater in the study areas ranged from NA ( not applicable) and to 0.026, and for manganese $(\mathrm{Mn})$ through the ingestion of groundwater on the study areas ranged from NA to 0.24 , and for zinc $(\mathrm{Zn})$ through the ingestion of Groundwater on the study areas ranged from NA to 0.008 , and for copper $(\mathrm{Cu})$ through the ingestion of groundwater on the study areas ranged from NA to 0.03 .

The average hazard quotient (HQ) for risk assessment due to intake of iron, manganese, zinc and copper through the ingestion of groundwater in the study areas is less than 1 meaning that no Significant risk or systemic toxicity

In addition, no threat to the local people for Wadi El-Natrun, Kom Hamada and El-Dilingatearas. Table 5 show that (average hazard index (HI)) for risk assessment due to intake of iron and manganese and zinc and copper through the ingestion of groundwater in the study areas ranged from NA to 0.262 this value of hazard index (HI) is less than 1 means the exposed population is assumed to be safe.

These results were in agreement with (Giri et al., 2012) studied the hazard quotient (HQ) for risk assessment due to intake of heavy metals through the ingestion of groundwater on ten groundwater samples collected from each sit Bagjata and Banduhurang area, India taking into account average water consumption of $1.48 \mathrm{~m} 3$ year $^{-1}$ by an Indian adult. The HQs of all the considered heavy metals were below the threshold value of 1 as suggested by (USEPA, 1993). Where hazard quotient (HQ) for $\mathrm{Fe}, \mathrm{Mn}, \mathrm{Zn}$ and $\mathrm{Cu}$ are $0.05,0.84,0.11$ and 0.01 respectively in Bagjata area, hazard quotient (HQ) for $\mathrm{Fe}, \mathrm{Mn}, \mathrm{Zn}$ and $\mathrm{Cu}$ are $0.04,0.58,0.08$ and 0.01 respectively in Banduhurang area. The hazard quotients of all the considered heavy metals for drinking water were below 1 posing no threat to the local people for both Bagjata and Banduhurang mining area, India.

Table 5:- Average hazard quotient (HQ) for heavy metal due to exposure through ingestion of groundwater.

\begin{tabular}{|c|c|c|c|c|c|}
\hline \multirow[b]{2}{*}{ Well name } & $\mathbf{F e}$ & Mn & Zn & $\mathbf{C u}$ & \multirow{2}{*}{$\begin{array}{l}\text { Average hazard } \\
\text { index }\end{array}$} \\
\hline & $\begin{array}{c}\text { average } \\
\text { HQ }\end{array}$ & average $H Q$ & average $H Q$ & $\begin{array}{c}\text { Average } \\
\text { HQ }\end{array}$ & \\
\hline BanisalamaElkadiem & 0.026 & NA & $\mathrm{NA}$ & NA & 0.026 \\
\hline BaniSalamaElgdied & 0.003 & NA & NA & NA & 0.003 \\
\hline ElMadinaElsakinia & NA & NA & NA & NA & NA \\
\hline NadyElsid & $\mathrm{NA}$ & NA & $\mathrm{NA}$ & NA & NA \\
\hline ELHamra & 0.006 & 0.02 & 0.004 & NA & 0.03 \\
\hline Mghnine & 0.002 & 0.068 & NA & NA & 0.07 \\
\hline Wakied & 0.013 & NA & 0.008 & 0.03 & 0.051 \\
\hline ZawietElbihre & 0.009 & 0.051 & NA & NA & 0.06 \\
\hline El Tod & NA & NA & NA & NA & NA \\
\hline Elwfiea & 0.012 & 0.013 & NA & NA & 0.025 \\
\hline Abo smada & 0.012 & 0.068 & NA & NA & 0.080 \\
\hline EbiaElHamra & 0.022 & 0.24 & NA & NA & 0.262 \\
\hline Min. & NA & NA & NA & NA & NA \\
\hline Max. & 0.026 & 0.24 & 0.008 & 0.03 & 0.262 \\
\hline Average & 0.012 & 0.077 & 0.006 & 0.03 & 0.068 \\
\hline
\end{tabular}

NA: not applicable

\section{Conclusions:-}

Groundwater is an important source of domestic, industrial and agricultural water supply in Egypt and the world.The most of wells in the study areas not complying with (WHO, 2011) guidance level for ${ }^{226} \mathrm{Ra}$ and ${ }^{228}$ Raradionuclides for members of the public $(1.0$ and $0.1 \mathrm{~Bq} / \mathrm{lrespectively)}$. The total annual effective radiation of doses due to the water consumption violated the allowable limits of WHO - which is $\left(0.1 \mathrm{mSvy}^{-1}\right)$ and the expected annual cancer risk doses due to water consumption in the study areas violated the allowable level, of WHO which is $\left(5.5 \times 10^{-}\right.$ $\left.{ }^{6}\right)$.Health risk assessment of heavy metals for population in the study areas posing no threat to local people. The monitoring of the groundwater quality from the different pointsinEl-Beheira governorate should be carried out on monthly base and modern and accurate techniques for treating the groundwaterto get rid of the radionuclides and different pollutants should be applied to save the health of all population. 


\section{References:-}

1. Ahmed, N.Kh.,( 2004): Natural radioactivity of ground and drinking water in some areas ofupperEgypt, Turkish J. Engineering.Environment.Science 28, 345 - 354.

2. Ahmed, M.A., Abdel Samie, S.G., El-Maghrabi, H.M., (2011): Recharge and contamination sources of shallow and deep groundwater of pleistocene aquifer in El-Sadat industrial city: Isotope and hydrochemical approaches, Environmental Earth Science 62:751-768.

3. Ajayi, O.S., Adesida, G., (2009): Radioactivity in some sachet drinking water samples produced in Nigeria, Iran.Journal. Radiation Researche, 7 (3): 151-158.

4. Allam, A.R., Saaf, E., Dawoud, M. A., (2002): Desalination of brackish groundwater in Egypt Desalination. 152:1926.

5. Badawy, W. M., El-kameesy, S. U., Soliman, N. F., Eissa, H. S., Mahmoud, A. W., (2015): Natural Radioactivity and the Associated Dose from the Terrestrial Ecosystemof Ismailia Canal, Egypt, International Journal of Advanced Research Volume 3, Issue 1, 768-778.

6. Benes, P., Strejc, P., Lukavec, Z., (1984): Interaction with radium and freshwater sediment and their mineral components: I. Ferric hydroxide and quartz. Journal Radioanal Nuclear chemistry 82:275-285.

7. Benes, P., Borovec, Z., Stejc, P., (1985): Interaction with radium and freshwater sediment and their mineral components: II. Kaolinite and montmorillonite. J RadioanalNuclier Chemistry 89:339-351.

8. El-Awady, M.M., Atwia, M.G., El-Nikhely, A.H., Hamouda, A.Z., (1997): Chemistry of groundwater in wadi ElNatrun area, western desert, Egypt, vol 3. The Third Conferenc on Geochemistry, September 3-4, Alexandria University, Faculty of Science, pp57-67.

9. El-Gamal, H., Abdel Hamid, M., Abdel Mageed, A.I., El-Attar, A.L., (2012): ${ }^{226}$ Ra, ${ }^{232}$ Th and ${ }^{40} \mathrm{~K}$ analysis in water samples from Assiut, Egypt, XI Radiation Physics \& Protection Conference, Nasr City - Cairo, Egypt, November 25$28,2012$.

10. El-Gamal, H., Farid, M.E., Abdel Mageed, A.I., Bady, M., Hasabelnaby, M., hassanien, H.M., (2013): Monstrous hazards produced by high radioactivity levels around Assiut thermalpower plant. American Journal of Environmental Science 9 (5): 388-397.

11. El-Naggar, H.M., (2010): Development of low-cost technology for the removal of iron an manganese from groundwater in Siwa oasis, Journal Egypt Pilbiic Health Association,Vol. S5 N. 3 and 4.

12. Fahim, F.A., Mousa, S.A., Abdel Aleem, M. K., (1995): Studies on the groundwater at an agricultural area, Nile delta, Egypt. Proc. 1st international conference on the environment and developmentinAfrica.Vol. 1. Assiut, Egypt, Assiut university center for environmental studies. 215.

13. Gerba, C.P., (2006): Risk assessment.in: Pepper, I.L., Charles P. Gerba, C.P. and Brusseau, M.L. (eds.) Environmental and Pollution Science. 2nd Ed. USA: Elsevier.

14. Giri, S., Mahato, M.K., Singh, G., Jha, V. N.,( 2012): Risk assessment due to intake of heavy metals through the ingestion of groundwater around two proposed uranium mining areas in Jharkhand, India, 184:1351-1358.

15. IAEA, International basic safty standards for protection against ionizing radiationand for the Safetyof radiation sources. Safety series 15, Vienna, (1996).

16. ICRP, 2008. The 2007 recommendations of the International Commission on Radiological Protection,ICRP Publication 103. Annals of the ICRP, 37(2-4).

17. Ministry of Health, (2007): Criteria for potable water. Egyptian Ministry of Health, Cairo.

18. Nickson, R.T, McArthur, J.M, Shrestha, B., Kyaw-Nyint, T.O., Lowrt, D.,( 2005): Arsenic and other drinking water quality issues, Muzaffargarh district, Pakistan. Appllied Geochemistry 20:55-68.

19. OEHHA, (2003): The air toxics hot spots program guidance manual for preparation of health risk assessments. Office of environmental health hazard assessment, California Environmental Protection Agency.

20. Rowland, R.E., (1993): Low-level radium retention by the human body: A Modi_cation of the ICRP publication 20 retention equation". Health Phys, 65,507-513.

21. Sevgi, E., Coral, G., Gizir, A.M. and Sagun, M.K., (2009): Investigation of heavy metal resistancein some bacterial strains isolated from industrial soils [J]. Turk Journal of Biology 34: 423-431.

22. Stamatis, G., Voudouris, K. and Karefilakis, F., (2001): groundwater pollution by heavy metals in historical mining area of Lavrio, Attica, Greece, Water, Air, and Soil Pollution 128: 61-83.

23. Tawalbeh, A.A., Samat, S.B., Yasir, M.S., Omar, M., (2012): Radiological impact of drinks intakes of naturally occurring radionuclides on adults of central zone of Malaysia. The MalaysianJournal of Analytical Sciences, Vol 16 No 2: $187-193$.

24. US-EPA, (1993): Carcinogenicity assessment. IRIS (Integrated Risk Information System), 2003. US Environmental Protection Agency, Washington DC, USA.

25. WHO, (2011): World Health Organization, guidelines for drinking-water quality, fourth edition.

26. Wrenn, M.E., Durbin, P.W., Howard, B., Lipsztein, J., Rundo. J., Still, E.T., Willis, D.I.,(1985): Metabolism of ingested U and Ra. Health Physical 48, 601-633. 